\title{
An Unstable Equilibrium and Process of Becoming in All This Can Happen
}

Florence Freitag

\begin{abstract}
All This Can Happen is explored as an "unstable equilibrium" with one essential raison d'être: movement. The term "unstable equilibrium" is taken from Maya Deren, as she relates it to her own films as being in a constant process of ritualistic becomingness. The alternation of images - the cinematographic choreography-is what makes All This Can Happen a film that enables us to discover movement in its purest forms and actions, especially because things are made to move. It is the "unstable equilibrium" of these pictures and their in-between, a balance of different visual and motional dynamics, that develops into an understanding and becoming of movement.
\end{abstract}

Keywords: Unstable Equilibrium, In-Between, Becoming, Maya Deren, Gilles Deleuze

The concept of absolute, intrinsic values, whose stability must be maintained, gives way to the concept of relationships which ceaselessly are created, dissolved and recreated and which bestow value upon the part according to its functional relation to the whole. We face the problem of discovering the dynamics of maintaining an unstable equilibrium. ${ }^{1}$

This is how filmmaker Maya Deren, in 1946, describes what it means for her to maintain an unstable equilibrium, a term that she attributes to her father, a Russian psychoanalyst. Dedicating her essay "Cinema as an Art Form" to her father, Deren writes: "To my father, who, when I was a child, once spoke to me of life as an unstable equilibrium." ${ }^{2}$ She uses the term to describe the human condition of her time.

"Cinema as an Art Form" is published in the same year as Deren's most developed text on filmmaking, An Anagram of Ideas on Art, Form, and Film ${ }^{3}$ (1946), and the release of Deren's fifth film, Ritual in Transfigured Time. In the essay, Deren not only advocates the possibilities of film as a time-space art, but also writes about the need to explore it as an independent art form, able to create and offer new realities reflecting actual changes in life and society. ${ }^{4}$ Later on in the text, Deren emphasizes the idea of adjustment to an ever-changing - hence ever moving - world and to life as being in a state of constant reconfiguration. The state of being human is at the same time "constant enough to constitute an identity" and "adjustable enough" 5 to changing

The International Journal of Screendance 7 (2016). 
circumstances. Influenced by the changing social, technological, and human conditions, Deren conceives of her films as a balance between states, as uninterrupted tension and opposition. These notions of states and tensions are echoed in the writing of French theorist Gilles Deleuze, who, in Cinema 2: The Time-Image, describes inbetween tensions as "intervals," ${ }^{\prime 6}$ and as the driving forces of film. This article will draw on Deren's filmic work and her notion of unstable equilibrium, as well as on Deleuze, to investigate the different forms of movement present in All This Can Happen.

In this article, the film All This Can Happen is explored as a visually choreographed poem that is driven by the dynamics of being an unstable equilibrium, a controlled coincidence, a state of the in-between with one essential raison d'être: movement. I argue that All This Can Happen is an essayistic filmdance, or "ciné-poem," the choreographic interplay and the rapid alternation of images and visual gestures which enables the viewer to discover movement in its many forms and varieties. It is the simplicity of the movement of everyday things that is brought to life in the film: people, cars, hats, flowers, birds, a window opening, or a door closing. Everyday things that a walker-like the one in Robert Walser's Novel The Walk ${ }^{8}$-might encounter on his/her way.

An essayist, according to Max Bense, on film or on paper, is "a combinatory person, a tireless producer of configurations on and around a specific object." ${ }^{\prime 9}$ Essay-writing can be like a thought that moves on constantly, on its way to seeking meaning for something that may not have a stable significance. It is an unstable process much like a film, the ever-changing becoming of something else, an aimless undertaking, the end of which is unknowable. Aimless, in the way that Walser's walker did not seem to follow any preconceived road. Both essays and films tend to have clear endings, but their ritualistic effects, their reverberation in our minds, are continuous, like the ritualistic becoming of Walser's walking protagonist.

How then might an investigation of unstableness in Deren's oeuvre help a reading of Davies' and Hinton's film and its effects and affects? This article aims to show that the spectator of All This Can Happen relates to the moments in-between the images in specific ways. Furthermore, this article reads the moving motion picture as both an homage to the humble flâneur Robert Walser and as a visual peripateticism ${ }^{10}$ of its own. Finally, this article attempts to constantly be moving forward as a becoming work of moving thinking.

\section{Unstable Rituals}

The online Oxford dictionary defines an unstable equilibrium as a "state of equilibrium in which a small disturbance will produce a large change."11 When something changes, it can become something else, even though the change may be small and happening very slowly. Maya Deren understands the unstable equilibrium as a balance between 
different states and conditions, be they technological or human. Balancing indicates a notion of relations, or "meshes" of relations that make changes happen.

As Sarah Keller writes in her recent publication Maya Deren: Incomplete Control (2014), the unstable equilibrium could be seen as an "artistic strategy" employed by Deren. ${ }^{12}$ As part of this approach, Deren both creates a structured form and fills it with "nonnarrative, nonlinear meaning."13 Meaning is hereby generated through deconstructed spaces and depersonalized protagonists, and meaning is suggested rather than fixed. For Deren, openness - that is, "incompletion" and "open-endedness" -is "the essential nature of art,"14 intended to constantly shift the viewer's perspective and experience-for example, with the help of juxtaposed psychological conditions or associations. Nevertheless, and in spite of an attitude of openness, Deren makes use of a clear structure, or form, in her films. She writes about her 1946 film Ritual in Transfigured Time:

I would like to use the word 'classicist' to describe Ritual in Transfigured Time precisely because it does not define according to the elements of the content-factual, fictional, abstract, or psychological. It is a concept of method: a controlled manipulation of any or all elements into a form which will transcend and transfigure them. ${ }^{15}$

According to Keller, this method implies a constant play between control and release. ${ }^{16}$ In that sense, art mirrors what takes place in rituals. According to Deren,

a ritual is an action distinguished from all others in that it seeks the realization of its purpose through the exercise of form. In this sense ritual is art; and even historically, all art derives from ritual. In ritual, the form is meaning. ${ }^{17}$

Deren controls the work through the form of her films, through the above-mentioned "controlled manipulation," as, for example, in Meshes of the Afternoon (1943); At Land (1944); and, most explicitly, in Ritual in Transfigured Time (1945-1946). Ritual, together with the notion of unstable equilibrium, constitute Deren's particular interests during this period. Engaging with what happens if control and release work together, she explores the "deference of personality in possessed states of being." 18 The controlled ritual is deployed as the form that both contains and allows for play. Rita Christiani, friend and performer in Deren's films, says about this period: "It was though she were looking for something. She knew what it was, but she just could not verbalize it, within the confines of a mind." 19 Accordingly, Deren needed to visualize and express it in images and through her bodily experience and expression, mainly by discovering the ritualistic states in Haitian Vodun between 1947 and 1955. Those experiences then were transposed onto her films. 
Through the Haitian Vodun religion, Deren found a means to give "credibility to the unreal" ${ }^{\prime 2}$ and to unite different temporalities. The latter is explored also in Deleuze's writing. Deleuze defines his concept of becoming as a process of going "back into the event, to take one's place in it as in a becoming, to grow both young and old in it at once." ${ }^{21}$ Becoming does not mean returning to the past but entering a state in which one is open for new relations and possibilities through past events. As anthropologists João Biehl and Peter Locke write, "In becoming, as Deleuze saw it, one can achieve an ultimate existential stage in which life is simply immanent and open to new relations-camaraderie-and trajectories." ${ }^{22}$ It is a whole process, nourished from experiences and combining temporalities. During the ritual, the living and the dead, the past and the present come together. A living body becomes an ancestral deity and the servant body transcends itself, reminiscent of the way in which Deren transcends personalities and identities in her films through exchanging characters (e.g. the changing identities of the man walking next to her in At Land) ${ }_{1}^{23}$ sudden disturbances, and ritualistic dances. Indeed, in her early works, Deren used discontinuity and fragmentation to hint at psychological disturbances and diverging or converging constitutions of her protagonists.

In Deren's Meshes of the Afternoon, ${ }^{24}$ small changes produce an imbalance-in the image, in the form of unexpected occurrences-and contribute to the creation of a feeling of mystery, or instability around the protagonist's identity. Something within the work is out of balance, and things appear to have happened in the past that the spectator does not know about. This ongoing uncertainty gives the film a sense of instability. Deren cuts out chunks of time, makes use of the jump cut, and produces loops that connect situations or scenes that have happened at another point in time, bringing closer together spaces that are distant. As the distances shrink, space is understood as something that can easily be transcended and transformed. As Keller writes, continuity and discontinuity build up new geographies, and, "space and time are furnished with flexible dimensions and can expand or condense places and moments." ${ }^{25}$ The spectator experiences an instability that is achieved through discontinuity and fragmentation.

Compared with Meshes of the Afternoon, Deren's second film, At Land, takes the instability not from the inside of the protagonist, but through the representation of the outside world and its different dynamics. In the opening shot, the solo protagonist, played again by Deren, is thrown out of the water onto land, immediately challenging the viewer's perceptions of real time and continuous space, as the seawater runs backwards down her body. The protagonist also realizes that the spaces and places she is looking for are always already changed and different when she arrives. This produces a precarious relation between body and space, where the latter never stays the same. 


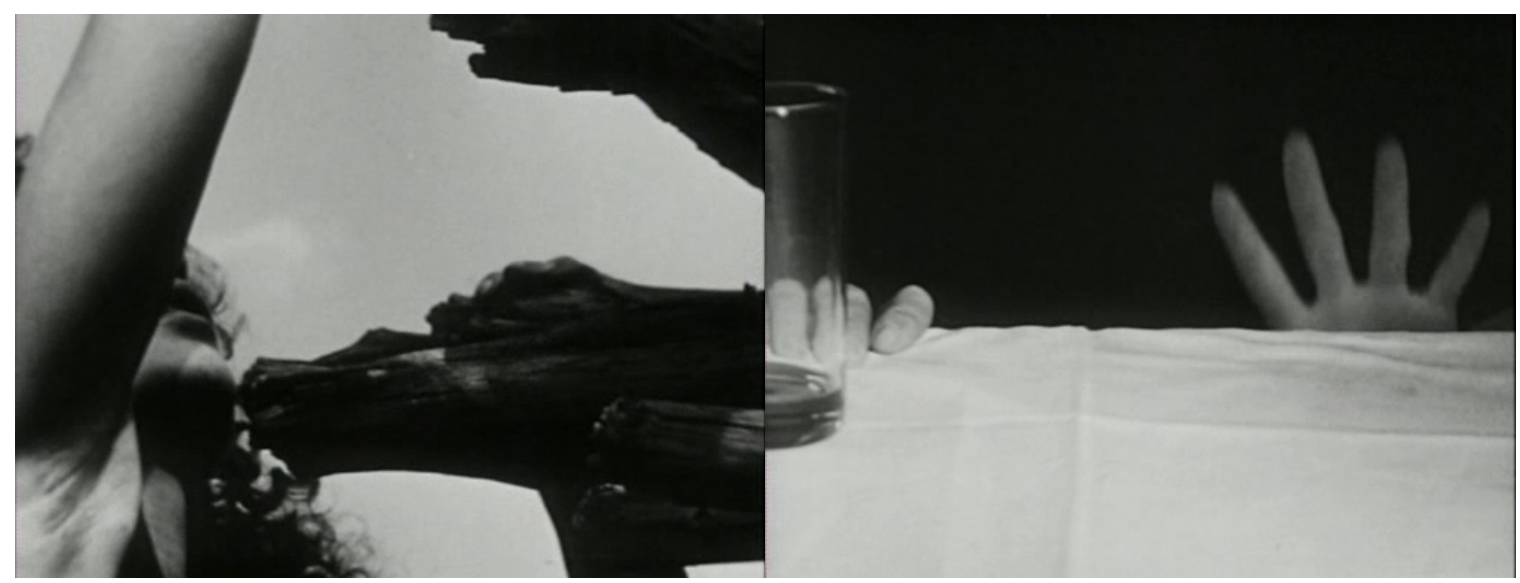

Screenshots of At Land. Dir. Maya Deren, 1944.

Everything appears to be incoherent in this Odyssey. Near the end of the film, Deren as the protagonist picks up stones on the beach in haste, without paying attention to them constantly falling down. All of a sudden she lets them all fall, attracted by something else. The next image shows her in front of two women playing chess. The women are sitting next to each other, and Deren is going through their hair with her hands before abruptly taking one of the chess figures from the table and running away with it. As in her first film, Deren tries to put the viewer into a kind of trance, choreographing the edit so that the viewer identifies with the "mental states" 26 of the protagonist. The states are realized furthermore through visual, dreamlike images, wandering bodies and objects that construct a disjunctive space and time. Continuity is not found in the image, but created through connecting movements.!

These psychological and mental states are part of the unstable equilibrium in Maya Deren's work and can be related to the "thinking feeling" of her "Choreo-Cinéma" in the way that the latter is happening through a kind of "cinematic thinking." 27 Deren herself explores this in her lecture "Planning by Eye" from 1947, first published in Film Culture \#39 in late 1965, by comparing "individual" and "industrial" films. ${ }^{28}$ By "planning by eye" Deren means to show on screen only the ideas that she could see or draw, hence choosing also for her films to be silent. ${ }^{29}$

\section{Material and Form in All This Can Happen}

The unstable equilibrium in the viewing experience of All This Can Happen is achieved through variations and repetitions of detached and re-contextualized images and incompatible and reconnected spaces, bound together by the imaginative editing choices of choreographer Siobhan Davies and filmmaker David Hinton. Meanwhile, the narration of Walser's walk activates, like Deren's precariously balanced protagonists, the inner moving images of the viewer. Walser's text articulates a process of change and becoming: "I was no longer myself," he claims, "I was another, yet it was on this account that I became properly myself." ${ }^{30} \mathrm{He}$ may as well have been 
writing about being possessed! And while there is spoken word that forms a sort of narrative, Davies' and Hinton's film relies on the whole visual body of the film to build a visual poem. The film is "written" through different devices and "thinks" through the images. The unstable equilibrium is established from one image to the next, "through the frame, from one frame to the next, ${ }^{\prime 31}$ as Deren would have said.

Much like a dancer might work on his or her choreographic material, rearranging and transforming it, the filmic material from the First World War recordings, psychiatric hospitals, and the first cinematographic experiments from the turn of the last century is doubled, stilled, slowed down or accelerated, and paired. The text is at the same time a mise-en-abime of this walk and a dancing writing full of descriptions and details. ${ }^{32}$ It is as if Walser notices "every smallest living thing" ${ }^{\text {"33 }}$ around him, writing down every minute he experiences.

All This Can Happen builds a momentum through both the quick succession of (moving) images, and of the interstices that occur between these images. The spaces between images bring to mind French theorist and writer Raymond Bellour's notion of "entre-images," a contemporary construction of multiple spaces through the use of various images; from film to photography to video material. ${ }^{34}$ Eivind Røssaak, in his anthology Between Stillness and Motion, makes use of Bellour and describes the screen work of Gregg Biermann as a "multiplicity of images." ${ }^{35} \mathrm{His}$ characterization can also be applied to Davies and Hinton's film:

Cinematic motion as the movement of objects in space within the image is here competing with the movement between blocks of floating images. The blocks float like moving pictures through the screen like an approaching bullet or projectile. Ultimately, a labyrinth of movements appears both within the image (the image within the image) and between the images (the changing relationship between the images within the images). Continuity editing is replaced by discontinuous and labyrinthine editing process, and the screen no longer displays one image at a time, but several. ${ }^{36}$

All This Can Happen does, however, not begin with this play of multiplicities. Instead, it is developed slowly and builds up as the film goes on. The first thing the viewer encounters is a single, framed, black and white recording of a man sitting in a bed, staring intently back at her/him. 


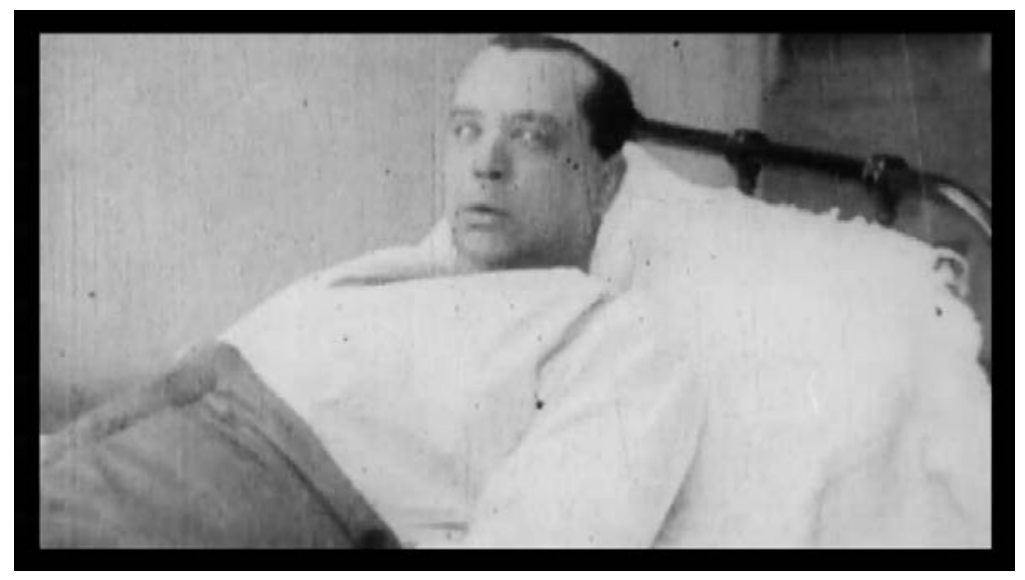

Screenshot of All This Can Happen by Siobhan Davies and David Hinton, 2012. "War Neuroses: Netley Hospital 1917." Courtesy of the Wellcome Library, London.

The footage is looped, so that the man's head trembles from side to side. The materiality of the footage-its flickering and visibly aged nature-make it evident that these images are from a past era. They create a ghostly time-space somewhere between still and moving, producing, however, a remarkable experience of nowness. The man seems trapped in his bed, bound to it. The image then fades into another black and white recording of misty trenches-men, presumably soldiers, rolling down a hill —and out again to the man on the bed, as if we were diving into his memory. He appears to be/become the first protagonist. The looped image suggests that he is unable to move but has a desire to move and, in the following split screen-a first association of images - we see another man trying to walk, stand up, and fall. His attempt is arrested mid-movement and then repeated. Both men appear to be ill. They are unable to control their movements-possibly a symptom of illness. The historical context of the images-a supposedly psychiatric environment-and the presumed illness of the patients both contribute to the creation of a highly visceral experience of movement and stillness for the viewer. Significant in this chain of images is the framing of the movement, which contributes to the construction of meaning through association across images.

Movement is progressively foregrounded and brought into focus in All This Can Happen. The use of framed, split, or doubled images is the essential gesture of the film. The filmic recordings are reinvestigated, stilled, and brought back into motion. The same happens with the photographic material, edited in what could be called a contrapuntal affection between image and text on different levels. Not only is there an explicit relationship between Walser's text and the images, with the text commenting on the images, but also and especially between the images themselves through their very own pictorial logic. The term contrapuntal, borrowed from musical baroque and renaissance composition, indicates a polyphonic aesthetic. Such an aesthetic neither emphasizes harmony nor discounts it, but it simply employs a counterpart that rings out at the same time as the main melody. The counterpoint does not happen because of harmony, but in spite of it. In All This Can Happen, the main melody could be seen to 
be the text against which the images have been juxtaposed in a cinematographic détournement, whereby each image is given a new intention. The images, one could say, "the danced archive," trigger intermedial references that happen within the film, and that will be different for different viewers. The relationships between the images affect the meaning of the single image, and allow them to become alive.

This particular use of recontextualised images in All This Can Happen brings to mind other art films where photographs are used to create the work. Liv Hausken, in Røssaak's anthology, calls such a work a "slide-motion film." ${ }^{37}$ Hausken writes about films, like La Jetée by Chris Marker, in which the camera seems to be moving within the images, panning and zooming through the photographs. ${ }^{38} \mathrm{It}$ is a moving picture in the best sense of the word. This sliding is used in All This Can Happen, for example, when the imaginative walker continues his way out of the city and into the woods. The camera is still at first and then pans to guide the eye of the spectator across the image, and through the woods.

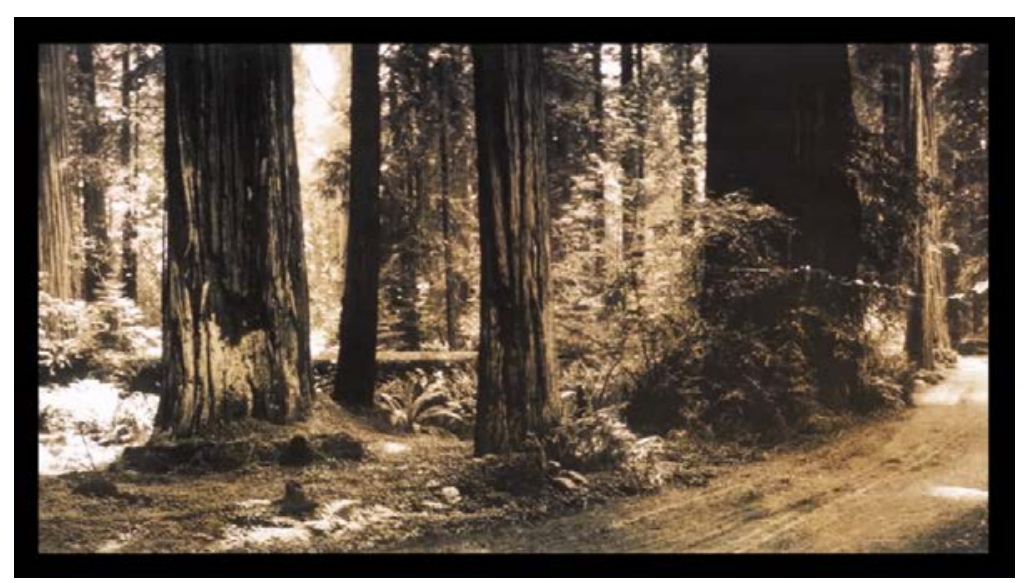

Screenshot of All This Can Happen by Siobhan Davies and David Hinton, 2012. "Gods Handiwork" 1912 (S U Bunnell). Courtesy of Library of Congress Prints and Photographs.

It is a false pan-there is no camera, but it has the effect of changing our perception and causing our eyes to scan the image. This process is not unlike touch; it is a static image being touched with the eyes. The viewer feels engaged in the scene through that movement, just as the viewer follows the panning camera in the woods at the beginning of Deren's A Study. In both cases, the viewer builds expectations as to what might be seen next, and the filmmaker plays with this build up of expectations. Davies and Hinton chose to maintain and emphasize the motion, rather than focusing on the stillness of the photograph. By doing so they take the viewer through the film, moving him/her.

\section{Discontinuity and the Protagonist's Body}

Developing a particular "visual logic" of cinema, Deren played with spatial, temporal, and filmic parameters to create changing perspectives and cinematographic geographies, causing the viewer to experience time and space in unusual ways. ${ }^{39}$ In All This Can Happen, the imaginative walker/traveller and the viewer, also, traverse 
disparate spaces, but in different ways. Whereas Meshes or A Study engages the viewer in following Deren's protagonists, All This Can Happen does not propose this kind of identification with a single body.

The walker of All This Can Happen wanders through the city and the woods, but the spectator does not see him. There are roads, fields, bookshops, living rooms, and many people in the images, so that the walker is not represented by one distinguishable body, but by several figures at different times. Sometimes, the single body is hidden in the in-between, inviting the viewer to take his or her place in amongst the crowd.

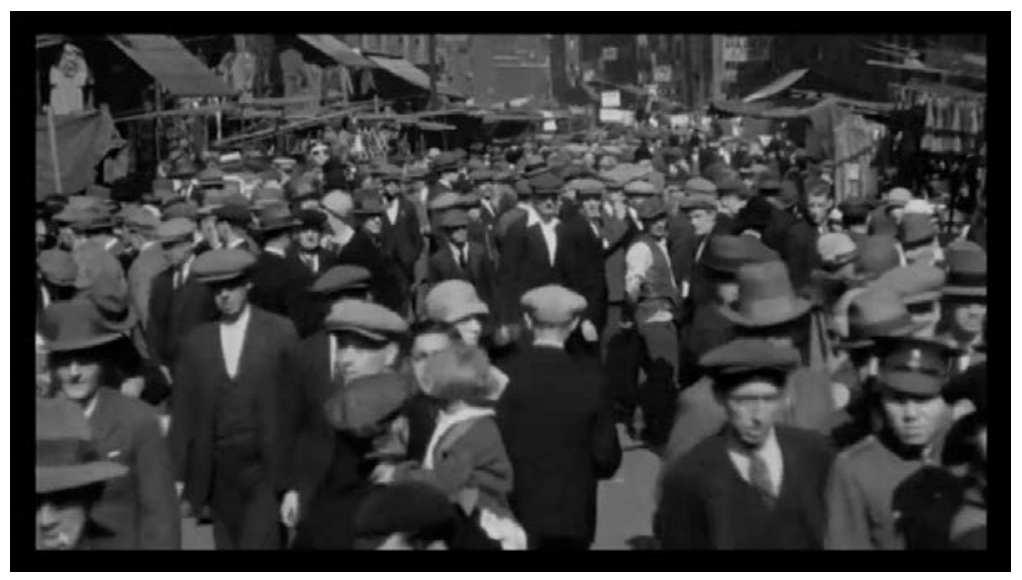

Screenshot of All This Can Happen by Siobhan Davies and David Hinton, 2012. "The Open Road" by Claude FrieseGreene, 1925/6.

Space is perhaps experienced with a more personal engagement than in films that feature precise protagonists. In every visual happening and visually choreographed sequence, the viewer constructs the continuity of space through his or her own eyes. The space in Davies and Hinton's film relies on this interplay and interaction of the relations between images - the inside and outside of each image-as well as on the soundscape that accompanies the images and the narrated text.

Writing about Chris Marker's slide-motion film La Jetée in her book, Phenomenology and the Future of Film: Rethinking Subjectivity beyond French Cinema, Jenny Chamarette talks about a "cinematographic betweenness" 40 of bodies, technologies, and the outer world, of the film and of sound and image. According to Chamarette, Marker plays with "disembodiment" and "betweenness," 41 suggesting that the less a body (his own) is present in the image, the more the viewer is connected to that world, especially through the presence of the voice, which appears to slide over the different photographs. The disembodiment of the protagonist appears to act as a trigger for its opposite-embodiment-and sensorial engagement on the part of the viewer, within the filmic space and a sensorial feeling of the filmic space. ${ }^{42}$ The spectator fills in for the protagonist.

All This Can Happen also brings to mind Why Colonel Bunny was Killed by screendance maker Miranda Pennell. ${ }^{43}$ The film is composed of still photographs taken at the turn of the twentieth century. ${ }^{44}$ Pennell places the images one after the other and zooms 
into details of the pictures to tell the story "of a medical missionary on the Afghan borderlands" 45 in British India. A sense of movement that was not originally present in the visual material is constructed and offered to the spectator. The images are, and look, old; the haptic nature of their partly damaged material spreads a breeze of history towards the viewer, fusing the "now" and "then," as Pennell has argued in en earlier issue of the International Journal of Screendance. ${ }^{46}$ The juxtaposition of a soundscape, composed of music, spoken word, and other sounds, with the images determine the viewer's perception of the past. Pennell's intention of connecting times is expressed through editing a series of still photographic images together, and creating interspaces, or spaces between them. At the same time, the spaces inbetween the still images give the possibility to rest and pause and they create a sense of suspense, a moment of waiting for something to happen. As Pennell points out, "the photographic sequence makes for a potentially interesting dialectic between viewer and image, which can at once become a reflection on the past and an anticipation of the future-of-the past, the anticipation of cause and effect." ${ }^{\prime 7}$ There is a potential for different temporalities occurring at the same time, which recalls the multiple temporalities facilitated by rituals as discussed above.

The relational in-between of images opens up the interpretational possibilities of the film and makes the viewer "move" even between the still images. This tension between still and supposedly moving images entangles the viewer and draws her/him into the work. S/he may even find her/himself anticipating the next move, taking part in the ever changing, unstable state of moving consciousness and continuity. As Mark B.N. Hansen has argued in reference to Christian Metz's reading of Bergson: "to perceive motion, rather than represent it statically in a manner that destroys its essence, one must participate in the motion itself." 48

In order to participate, the viewer has to perceive and sense, think and walk, and be in a "thinking feeling" 49 of the medium, as well as in the world. This is reminiscent of Bergson's understanding of the whole and of duration, which for him is an internal, psychological, and qualitative movement of time, like a stream of consciousness, not reducible to space. In All This Can Happen, the viewer identifies with the depictions of details, the feelings and thoughts which Walser develops during his walking and visualizes again while writing. His inner time, his inner experiences, constitute the flow of his reality, building continuity out of something we usually perceive in small bits and pieces. In the film they are transformed through sliding, repetition, slowing down, or other editing techniques and connect with our inner, intuitive movement. ${ }^{50}$ The "cinematic thinking" and the "thinking feeling" thereby fall together in the viewer's unstable equilibrium. 


\section{Handing Over Movement}

If one was to summarize all the layers of All This Can Happen, it could be argued that movement is its core element: from the movement within each image and the passing from one to the other, to the movement of everyday gestures in the recorded material, and the movement of the walker whom one sees and hears talking about his walk.

To walk we have to lean forward, lose our balance, and begin to fall. We let go, constantly, of the previous stability, falling, all the time, trusting that we will find a succession of new stabilities with each step. ${ }^{51}$

This quotation from Robyn Skinner describes Maya Deren's unstable equilibrium through the act of walking. A walker has to adjust from one step to the next, not unlike the man falling right at the beginning of the film and trying to adjust to his instabilities. The filmic images similarly "initiate" each other and start an unpredictable flow of movement. It is a flow generated through a poetic aesthetic that is explicitly present in both Deren's oeuvre and Davies' and Hinton's film. It is not narrative meaning that comes first, but perception and experience, and a sense of the accidental. Nothing in All This Can Happen happens by chance, but the film gives the impression that all this can happen accidentally. According to Deren, the accidental experience defines poetic film: "Now poetry, to my mind, consists not of assonance; or rhythm, or rhyme, or any of these other qualities which we associate as being characteristic of poetry. Poetry, to my mind, is an approach to experience, in the sense that a poet is looking at the same experience that a dramatist may be looking at." ${ }^{52}$

All This Can Happen hands over movement from one image to the next, as well as through the splitting of the screen into many smaller screens. In his analysis of the slide-motion film Hausken reflects on the development of movement in the switching from one image, or one frame, to another. Hausken refers to Christian Metz: "[E]ven if each image is a still, switching from one to the next creates a second movement, an ideal one, made out of successive and different immobilities." ${ }^{53}$ It is curious that the succession of immobilities, as well as the stopping and starting of movement, would add up to a sense of constant movement. In a scene in which some girls are playing outside, movement is passed from one framed image to the next, as if there was a breeze traveling across them, animating the bodies of the images. The frame could be seen to function like a search screen, sliding over an animated reality and looking for something inside of it. ${ }^{54}$ As the voice over muses, "let them be unrestrained," ${ }^{55}$ the girls pull themselves from one frame into the next, their emerging movements being freed and passed on, liberating movement from its narrative form much like Maya Deren had intended.

This second, ideal movement, that occurs between the images, as Hausken writes, allows for an associative connection of images in the sense of a vertical way of editing. ${ }^{56}$ In this approach, where the physical movement is more important than 
character definitions, the dance unfolds. In All This Can Happen, the film's structure is based on combinatory and physical associations between images and words, creating additional layers, generating "another dimension," as Deren writes with regards to the use of words in vertical film form. ${ }^{57}$

The scene with the girls can be compared to a sequence of gestural dance that occurs in the film Ritual in Transfigured Time, a sequence that illustrates Deren's desire to create "dance out of non-dancing elements." 58 In Ritual it is not the bodies of the protagonists that connect distant spaces as they do in Meshes of the Afternoon, nor is it the movement of a single dancer, as in A Study. This scene is about one continuous movement going through the film, connecting the different characters and instances with each other. Deren's gestural dance points to the human condition more than towards meaning. As Deren argues, "what makes this a dance film, or a film-dance, is that all the movement-stylized or casual, full-figured or detailed-are related to each other, both immediately and over the film as a whole, according to a choreographic concept." ${ }^{\prime \prime}$

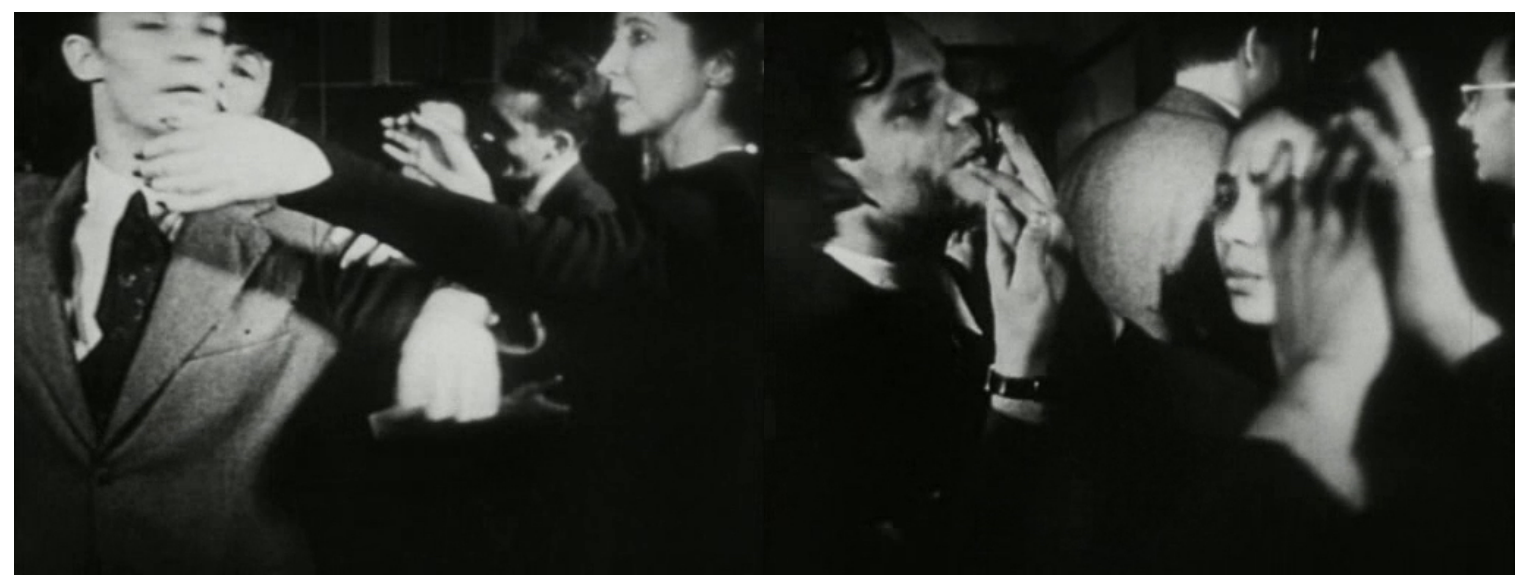

Screenshots of Ritual in Transfigured Time. Dir. Maya Deren, 1946.

Deren edits the guest's handshakes into a dance that freezes and starts again, thus forming the choreographic gestures of the film. The most important thing in these shots, as Deren argues, is "the emotional integrity of the movement itself." ${ }^{60}$ Variations on this technique can be found right across All This Can Happen, not least in the magical hat-scene, where a woman adjusts her hat in an 8-way split screen. 


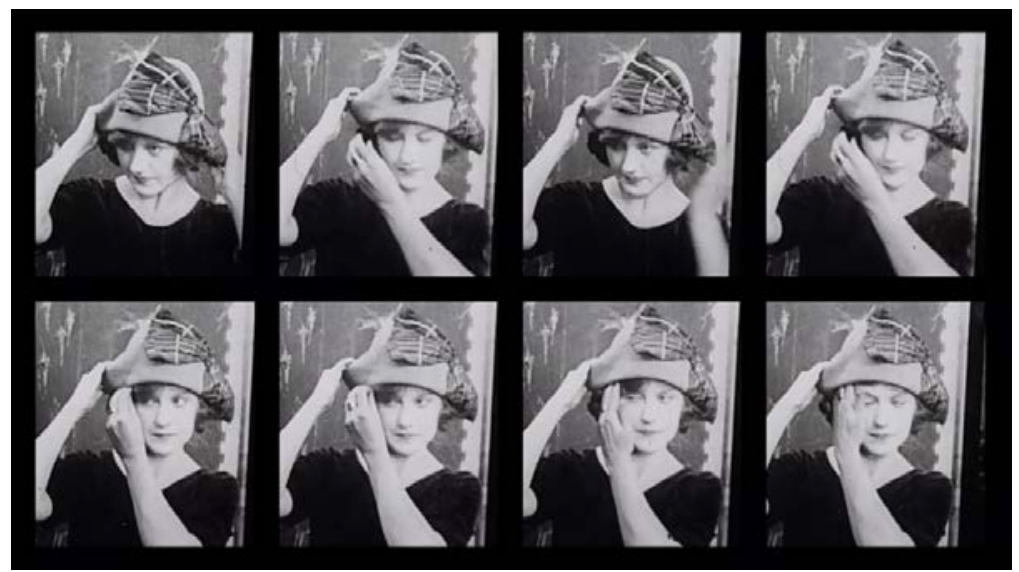

Screenshot of All This Can Happen by Siobhan Davies and David Hinton, 2012. 'Hints and Hobbies.' Courtesy of AP Archive British Movietone.

The images in this scene look like chronophotography, originally created to arrest movement in its spatial distillation in order to apprehend its timing, that is brought to life again. They bring to mind what Georges Didi-Huberman has called "la danse de toute chose," the dance of everything. ${ }^{61}$ For Didi-Huberman, "chronophotography supplements human perception," ${ }^{62}$ or, perhaps it sharpens and intensifies the viewer's perception, matching it to Walser's discernment on his walk:

In the water of a fountain a dog refreshes itself, in the blue air swallows twitter. One or two ladies in astonishingly short skirts and astoundingly high, snug, fine, elegant, dainty colored bootees make themselves conspicuous as anything else. Moreover two summer or straw hats catch my eye. ${ }^{63}$

As an essayistic "ciné-poem," All This Can Happen is an approach to life through the visualized peripateticism of Walser, his walking, talking, and seeing things. His perceptions of the world are transferred onto the spectators, involving the viewer in a multi-sensual walking science. But All This Can Happen does not address the viewer directly, as do, for example, the essay-films of Jean-Luc Godard, Wim Wenders, and others. Instead it mines the sensorial through the multiplicity of contrapuntal affections. Possibilities and chances of meaning and understanding and of recontextualisation are left open and allow for individual responses or interpretations. As argued by Sarah Keller about the possibilities and flexibility of expanding time and space with regards to Deren's work, ${ }^{64}$ the film is thereby somewhat incomplete and open-ended. ${ }^{65}$ Uncertain endings and uncertain narrative sequences underline the circularity and processual character of the work. Both All This Can Happen and Robert Walser's writing make use of this approach, and the wanderer/walker continuously, as Walser writes, "efface(s) himself in the contemplation and observation of things." 66

\section{Becoming}

Film, as Mark Alice Durant writes in an essay on Maya Deren, is about how one moment passes and becomes the next. ${ }^{67}$ The change does not appear in one frame 
but in what happens in the passage from one to another, in every in-between moment. This article has argued that All This Can Happen has its very own temporality, due to the difference in age between the varying images and the text. Together with the viewer's newness - to use Pennell's terminology ${ }^{68}$-one comes to feel the timelessness of the film, and the possibility that it could be seen and understood at anytime, anywhere. Durant writes that Deren, "spoke of the concept of time not being a fixed phenomenon, but something that was essentially subjective and unstable. She adopted Einstein's notion of the 'relativistic universe' to describe the idea of constant metamorphosis_of becoming as opposed to being. ${ }^{\prime \prime 9}$ Time, like movement is neither fixed nor bound to space; it changes. It changes like the images and like Walser's walking writing. In that sense, archival footage and photographies become infused by a feeling of present time. The transformation of the archival footage into digital film generates new movement, but with all the historical marks and hints included.

"Becoming as opposed to being" recalls the ritual, and Deleuze's idea of going back into an event and reliving it in some way. One may go back in time and into history, but the purpose is not the history of these images, the aim is to facilitate new perceptions and experiences. In other words, film exists always in the here and now. And within this nowness film can recall the eventfulness of the cinematographic gesture no matter when it was first caught on film. ${ }^{70}$

Finally to draw a final circle, another notion of becoming enters, as described by Martine Beugnet in her book Cinema and Sensation. ${ }^{71}$ Beugnet writes about the sensuous cinema, a cinema that returns to the flesh, to bodily experiences, and cites Deleuze and Guattari:

[B]ecoming is not to imitate or identify with something or someone. Nor is it to proportion formal relations. Neither of these two figures of analogy is applicable to becoming from the forms one has, the subject one is, the organs one has, or the function one fulfills, becoming is to extract particles between which one establishes the relations of movement and rest, speed and slowness that are closest to what one is becoming, and through which one becomes. ${ }^{72}$

The relations of movement and rest, speed and slowness are the characteristics of both film and dance, and constitute its play. Watching still or moving images can cause the viewer to feel moved without displacement, to be possessed by the image as in a ritualistic practice, to hover between the old and the new, and to transcend present time. The continuous process and unstable equilibrium in All This Can Happen create a ritual of passing images that move the viewer. Movements and images may be repeated, but every repetition has its difference. Every image, like every step, is a new leaning forward, a new discovery that the directors take the viewer through. The becoming of their idea of movement happens in the unstable equilibrium, in the 
auratic $^{73}$ visual - and in the union of crackling, visual processes and sonic layers of sensation. It is a walking reflection of living images that become, folding movement into new contexts, making connections with the spectator here and now.

\section{Biography}

Florence Freitag is working with moving images and moving bodies as director and videodance artist, performer, and curator/writer. She received an MA in Film and Audiovisual Media-Culture with a thesis guided by Maya Deren's "choreo-cinéma" and her voodooist presence. Freitag trained in dance between France and Germany. Inspired by life's shifting continuity, haptic kinesthetics, and everyday gestures, she is drawn to and involved in diverse multidisciplinary collaborations, including with Berlin-based dancers/choreographers, alongside working as videoeditor, as researcher/lecturer (e.g. Bauhaus-University Weimar), and as curator for the danceperformance platform "LUCKY TRIMMER." Her last videodance-trilogy in collaboration with DOP Johannes Plank has been shown internationally, including Loikka Dance Film Festival, Screendance Festival Stockholm, Short Waves Festival Poznan, Leeds International Film Festival, Lightmoves Festival Limerick, Dancescrecen London, FIVC, and DanceLab Nicosia

Email: florence.freitag@gmail.com

Website: http://www.florencefreitag.tumblr.com

\section{Notes}

1 Deren, "Cinema as an Art Form," 31.

2 Deren, "Cinema as an Art Form," 19. The essay was first published in the magazine New Directions 9.

${ }^{3}$ lbid.

${ }^{4}$ Ibid.,19-33.

${ }^{5}$ Ibid., 31.

${ }^{6}$ Deleuze, Das Bewegungs-Bild, 96.

${ }^{7}$ Maya Deren didn't use the exact term ciné-poem to describe her films. It is used to describe Man Ray's cine-poem "Étoile de Mer." However, Deren describes her films as poetic, or being like poetry: "If philosophy is concerned with understanding the meaning of reality, than poetry-and art in general-is a celebration, a singing of 
values and meanings." (Deren, "Manifestoes and Program Notes", in Essential Deren, 255).

${ }^{8}$ Translated for the first time in 1955. The text in All This Can Happen and this article are from a translation by Christopher Middleton from 1957.

${ }^{9}$ This is a free translation of Max Bense's quote: "Der Essayist ist ein Kombinatoriker, ein unermüdlicher Erzeuger von Konfigurationen um einen bestimmten Gegenstand," quoted in Faber, Der Collage-Essay, 8.

${ }^{10}$ The notion of peripateticism comes from the philosophical school founded by Aristotle and derives from the Greek peripatetikos, meaning walking, and from the adjective peripatetic, meaning meandering or wandering. We could say that Walser's writing has something of an Aristotelian movement-thinking. For Walser and his connection to peripaticism, see Huelle, Peripateticism.

${ }^{11}$ Definition from Oxford Dictionaries Online. In Maya Deren's films, this occurs in two different ways. For example, in Meshes of the Afternoon we can have large changes through little changes like the new position of the knife in her dreamlike meander through the house. Another large change happens with the help of a little editing of he footsteps. Within four steps, Maya as the protagonist traverses four different spaces and times and steps back into her house. Something little is happening, that always keeps something bigger moving, continuously.

${ }^{12}$ Keller, Maya Deren: Incomplete Control, 83.

${ }^{13}$ Ibid., 83

${ }^{14}$ Ibid., 68.

${ }^{15}$ Deren, "Ritual in Transfigured Time," 228.

${ }^{16}$ Keller, Maya Deren: Incomplete Control, 83.

${ }^{17}$ Deren, "Manifestoes and Program Notes," 252.

${ }^{18}$ Keller, Maya Deren: Incomplete Control, 85

${ }^{19}$ Christiani, in Keller, Maya Deren: Incomplete Control, 186.

${ }^{20}$ Rice, Inverted Odysseys, 17.

${ }^{21}$ Deleuze, Negotiations, 170.

${ }^{22}$ Biehl and Locke, "Deleuze and the Anthropology of Becoming," 317.

${ }^{23}$ At Land, Dir. Deren, 14 '00.

${ }^{24}$ Meshes of the Afternoon, Dir. Deren and Hammid, 14' 00.

${ }^{25}$ Keller, Maya Deren: Incomplete Control, 52.

${ }^{26}$ Holl, Kino, Trance, \& Kybernetik, 95.

${ }^{27}$ Deren, "Planning by Eye," 152.

${ }^{28}$ Ibid., 152.

${ }^{29}$ Ibid., 153.

${ }^{30}$ Walser, The Walk, 67.

${ }^{31}$ Deren, quoted in McPherson, Essential Deren, 132.

${ }^{32}$ Walser was inspired by the development of dance during the early years of the 20th century. He said, "It is my intention to dance with words." (Utz, Tanz auf den Rändern, 441) His sentences are very long, and he describes simple everyday life with 
sophistication. A frequent use of alliterations and pleonasms or tautologies make his humorous texts plastic and flowing.

${ }_{33}$ Walser, The Walk, 61.

${ }^{34}$ Bellour, L'entre-image.

${ }^{35}$ Røssaak, Between Stillness and Motion, 196.

${ }^{36}$ Ibid.

${ }^{37}$ Hausken, quoted in Røssaak, Between Stillness and Motion, 85.

38 Ibid.

39 Ibid.

${ }^{40}$ Chamarette, Phenomenology and the Future of Film, 106.

${ }^{41}$ Ibid.

42 Ibid.

${ }^{43}$ Pennell, "Why Colonel Bunny Was Killed."

44 Ibid.

45 Ibid.

${ }^{46}$ Pennell, "Some Thoughts," 74.

47 Ibid.

${ }^{48}$ Hansen, in Røssaak, Between Stillness and Motion, 52.

${ }^{49}$ Ibid., 53.

${ }^{50}$ See Bergson, Materie und Gedächtnis, 206.

${ }^{51}$ Skinner, in Huelle, Peripateticism in Robert Walser. Online.

52 Deren, in "Poetry \& The Film: A symposium." Online.

${ }^{53}$ Hausken, in Røssaak, Between Stillness and Motion, 90.

${ }^{54}$ Here we also could be thinking of Bazin's distinction between "cadre" and "cache." "Cadre" being the frame that collects the movement of the image in the inside and "cache" as a sort of mask that opens the image to the off, to the in between also of the images.

${ }^{55}$ Walser, The Walk, 15.

${ }^{56}$ Hausken, in Røssaak, Between Stillness and Motion, 90.

57 Deren, in "Poetry \& The Film: A symposium." Online.

${ }^{58}$ Deren, "Ritual in Transfigured Time," 225.

59 Ibid., 225.

60 Ibid., 225-226.

${ }^{61}$ Didi-Hubermann, Mouvements de l'air, 281.

62 Deren, "Ritual in Transfigured Time," 225.

${ }^{63}$ Walser, The Walk, 15.

${ }^{64}$ Keller, Maya Deren: Incomplete Control, 52.

${ }^{65}$ Ibid., 52

${ }^{66}$ Ibid., 60, 62.

${ }^{67}$ Durant, A Life Choreographed for Camera.

68 Pennell, Some Thoughts on 'Nowness' and Thenness, 72.

69 Durant, A Life Choreographed for Camera, 72. Italics are original, Boldings by the author of this essay. 
70 Görling, Im Medium Sein, in Görling, Skrandies, Trinkhaus, Geste, Bewegungen zwischen Tanz und Film, 275.

${ }^{71}$ Beugnet, Cinema and Sensation.

${ }^{72}$ Deleuze/Guattari, quoted in Beugnet, Cinema and Sensation, 129.

${ }^{73}$ This is of course in reference to Walter Benjamin's terminology of the "Aura" in his 1936 essay "The work of Art in the Age of Mechanical Reproduction." Here he describes the Aura of an art piece as the "Here and Now of the Original." Although Benjamin argues that the industrial art of filmmaking loses this auratic effect, it could be held against it that especially Maya Deren's filmdance can bring the experience of dance back via the medium film. The actualization and reinterpretation of the archive photography in All This Can Happen could have a similar effect.

\section{References}

All This Can Happen. Dir. Siobhan Davies and David Hinton. UK, 2012. Digital Video.

At Land (1944). Dir. Maya Deren. Paris: Re:Voir, 2008. DVD.

Bergson, Henri. Materie und Gedächtnis. Trans. J. Frankenberger. Hamburg: Felix Meiner Verlag $\mathrm{GmbH}, 1991$.

Bellour, Raymond. L'Entre-image: Photo, Cinéma, Video. Paris: La Différence, 2002.

Beugnet, Martine. Cinema and Sensation. French Film and the Art of Transgression. Edinburgh: Edinburgh University Press, 2007. https://doi.org/10.3366/edinburgh/9780748620425.001.0001

Biehl, João and Locke, Peter. Deleuze and the Anthropology of Becoming. Current Anthropology, 51: 3, (June 2010): 317-351.

Chamarette, Jenny. Phenomenology and the Future of Film: Rethinking Subjectivity Beyond French Cinema. London: Palgrave Macmillan, 2012.

https://doi.org/10.1057/97811372837400

Deleuze, Gilles. Das Bewegungs-Bild, Kino 1. Frankfurt am Main: Suhrkamp Taschenbuch Wissenschaft, 1989 (originally 1983).

. Das Zeit-Bild, Kino 2. Frankfurt am Main: Suhrkamp Taschenbuch Wissenschaft, 1990 (originally 1985).

. Negotiations, 1972-1990. New York: Columbia University Press, 1995. 
Deren, Maya. "Cinema as an Art Form." Essential Deren: Collected Writings on Film by Maya Deren. McPherson, B. (Ed.). Kingston, NY: Documentext, 2005 (originally 1946). 19-33.

. "Manifestoes and Program Notes." Essential Deren: Collected Writings on Film by Maya Deren. McPherson, B. (Ed.). Kingston, NY: Documentext, 2005 (originally 1945). 245-256.

"Planning by Eye." Essential Deren: Collected Writings on Film by Maya Deren. McPherson, B. (Ed.). Kingston, NY: Documentext, 2005 (originally 1947). 152-162.

. "Ritual in Transfigured Time." Essential Deren: Collected Writings on Film by Maya Deren. McPherson, B. (Ed.). Kingston, NY: Documentext, 2005 (originally 1946). 225228.

Didi-Hubermann, George and Manoni, Laurent. Mouvements de l'Air: Étienne-Jules Marey, Photographie des Fluides. Paris: Éditions Gallimards/Réunion des Musées Nationaux, 2004.

Durant, Marc Alice. "A Life Choreographed for Camera." Accessed 9 Jan. 2015. http://saint-lucy.com/essays/maya-deren/

Faber, Richard. Der Collage-Essay: Eine Wissenschaftliche Darstellungsform. Hildesheim: Gerstenberg Verlag, 1979.

Görling, Reinhold "Im Medium Sein" (2009); Geste, Bewegungen Zwischen Tanz, und Film. Görling, R., Timo Skrandies, and Stephan Trinkhaus, (Eds.). Bielefeld: Transcript Verlag, 2009. 267-292.

Holl, Ute. Kino Trance und Kybernetik. Berlin: Brinkmann \& Bose, 2001. . "Über die Kunst, an Land zu navigieren. Zu Maya Derens At Land" Gabriele Werner (Ed.) Bildwelten des Wissens Vol. 5.1: Systemische Räume. Berlin: Akademie Verlag: 2007. 40-51

Hongisto, Ilona. "Towards Embodied Knowledge? Maya Deren's Divine Horsemen - The Living Gods of Haiti and the Rupture of Ethnographic Documentary Film." Accessed 14 Aug. 2015. http://widerscreen.fi/2004/2/towards_embodied_knowledge.htm

Huelle, Shawn. "Peripateticism in Robert Walser." Accessed 19 Feb. 2015. http://www.3ammagazine.com/3am/peripateticism-in-the-work-of-robert-walser/ Meshes of the Afternoon (1943). Dir. Maya Deren and Alexender Hammid. Paris: Re:Voir, 2008. DVD. 
Nichols, Bill. Maya Deren and the American Avant-Garde. Berkeley, Los Angeles, London: University of California Press, 2001.

Oxford Dictionaries Online, Language Matters. “Unstable Equilibrium." Accessed 05 Sept. 2016. http://www.oxforddictionaries.com/definition/english/unstableequilibrium?q=unstable+equilibrium

Pennell, Miranda. "Some Thoughts on 'Nowness' and 'Thenness."' Scaffolding the Medium: The International Journal of Screendance. 2 (2012). 27-77. Why Colonel Bunny Was Killed. 28 minutes, HD. 2010.

_. "Writings About the Film Why Colonel Bunny was Killed." Accessed 31 Jul. 2016. https://mirandapennell.com/portfolio/why-colonel-was-killed/

Rice, Shelley (Ed.). Inverted Odysseys. Claude Cahun, Maya Deren, Cindy Sherman. Cambridge: MIT Press, 1999.

Ritual in Transfigured Time (1946). Dir. Maya Deren. Paris: Re:Voir, 2008. DVD.

Røssaak, Eivind (Ed.). Between Stillness and Motion: Film, Photography, Algorithms. Amsterdam: Amsterdam University Press, 2011.

Utz, Peter. Tanz auf den Rändern: Robert Walser's "Jetztzeitstil." Berlin: Suhrkamp, 1998. Walser, Robert. The Walk. Trans. C. Middleton with Susan Bernofsky. New York, NY: New Direction Books, 2012. 